\title{
The association between corporate social responsibility disclosure of cigarette company and company's financial performance
}

\author{
Amelia Desy Ratna Yuwita ${ }^{1}$ and Devi Sulistyo Kalanjati, ${ }^{1, *}$ \\ ${ }^{1}$ Universitas Airlangga, Indonesia
}

\begin{abstract}
This research examines the association between Corporate Social Responsibility (CSR) disclosure and financial performances-Return on Assets (ROA), Return on Equity (ROE), and Stock Return-within the cigarette companies listed on Indonesian Stock Exchange. This research used 3 cigarettes companies; PT Gudang Garam Tbk., PT Hanjaya Mandala Sampoerna Tbk., and PT Bentoel Internasional Investama. Simple linear regression is used to examine the association between CSR disclosure and the cigarettes companies' financial performance. The study reveals that the disclosure of CSR only has positive influences toward Return on Assets; yet, it does not correlate with the Return on Equity and Stock Return.
\end{abstract}

Keywords: Corporate Social Responsibility (CSR), Return on Assets, Return on Equity, Stock Return

\section{Introduction}

According to Act No. 402007 on Limited Liability Company (Perseroan Terbatas-PT) in Article 74 par (1), a company which conducts activities in the field and/or related to the natural resources is required to implement the Social and Environmental Responsibility. The company as a legal entity has to have a corporate social responsibility (CSR). The studies about CSR has growing rapidly caused by many cases where the companies did not make a positive contribution to the community and giving them a direct negative impact instead.

This research focuses on the CSR disclosure in the cigarette companies in Indonesia. Tobacco industry manages and utilizes the natural resources such as tobacco plants as main raw material. The tobacco industry in Indonesia, the fifth largest tobacco market in the world, has been established by the Indonesian government as one of the 10 major industries in the country which implied by the high number of employee recruitments and the contribution of industries in the country's income. According to [1], the tobacco sector in Indonesia has more than 4 million employees, including farmers, manufacturing sector employees, the sellers, and the distributors. In 2013, tobacco industry donated $95.79 \%$ of 155.82 trillion rupiah of the customs income to the country, or roughly $10.9 \%$ from the total of the country's income. They become one of the main pillars and driving forces of the Indonesian economy and their roles in increasing the growth of the national economy are parts of its positive contributions for the nation. Their CSR activities are also well known although at the same time, unfortunately, their main operating activities has a significant

* Corresponding author: Devi Sulistyo Kalanjati. devi.kalanjati@yahoo.com 
social impact on the health of human resources in Indonesia.

This study examines the relationship of CSR disclosure and corporate performances; ROA, ROE, and Stock Returns in companies engaged in the tobacco sector which also listed on the Indonesia Stock Exchange during 2007-2014. In 2007, the policy regarding the CSR disclosure in Indonesia was released; therefore the research results could be more legitimate and relevant in the present time. Meanwhile cigarettes companies are choosen because they have been criticized a lot by the community in general, because of the direct impact of their products are considered to be adverse to the human health. In this case, whether the disclosure of CSR has association with ROA, ROE and the stock return is important to be analyzed.

\section{Literature Review}

[2] in [3] define the CSR as actions that appear to further some social good, beyond the interest of the firm and that which is required by law. In short, the social responsibility is simply the reciprocal/payback of the company to the community and the surrounding environment, since the company has also taken the advantage of the community and the surrounding environment, which unfortunately the process of taking advantage from the company often causes damages to the environment and other social impacts.

According to the Financial Reporting Council [4], the disclosure of CSR activity can be viewed from various perspectives; level of disclosure, the theme of the disclosure, location or where such disclosure is made in the annual report, and also the type of disclosure. The level of disclosure range means that the amount of items disclosed are compared with the total amount of the items that should be disclosed. [5] mentions the themes included in the accounting of CSR are: social, employment, products, customer, and also the environment. The disclosure of CSR can be found in various ways, e.g. narrative qualitative, nonmonetary quantitative and monetary quantitative [6]. According to [7] there are some sections in the annual report such as in chairperson's report, operational review, corporate governance and CSR section. [7] also revealed that the most section used for social disclosure is in the CSR section.

[8] stated that the financial statement is designed for the decision makers, especially those outside of the company, regarding to the financial positions and the results of operation. The Ratio analysis shows the relationship between the elements of financial statements. expressed in the form of a simple mathematical [9]. [10] explains that the profitability ratio measures the company's ability to generate profits by using the resources of the company itself e.g. assets, capital, or company's sales. [10] also describes some of the ratios be used to calculate profitability among others are ROA and ROE. ROA is the ability to use assets to generate earnings after taxes. It measures the effectiveness and efficiency of the company's management in managing the assets. ROE shows the company's ability to generate earnings after tax by using the company's capital. ROE is a micro factor used by the investors to consider before taking the investment decisions.

Stock return is the income expressed as a percentage of the initial capital investment [11]. Stock returns is also an important factor that a prospective investor should consider before making a stock investment decisions. According to [12], the stock return can be divided into two; the stock realized and expected return.

The Act No 40 year 2007 in Section 74 about Limited Liability Company (PT) [13] states that: (1) Companies that have been in business related to the natural resources, are required to implement CSR. (2) The CSR referred in paragraph (1) is a mandatory that are budgeted and accounted as an expenses which its implementations are done in regard to decency and fairness. (3) The company that does not carry out the obligations referred in 
paragraph (1) will be sanctioned according to the established law. (4) Further provisions on CSR responsibility are regulated by the Government.

The CSR activities are part of good corporate governance. The activities are expected to raise the financial performance of the company because of their alignments to the public. The public is not only able to choose a good product by its value but also through its corporate governance. Logically thinking, if the people who become customers will have a positive assessment of the company, then they will be loyal to the products produced, which also would raise the image of the company and will be reflected through the increase in company's performance [14].

The companies of the cigarette industry are playing two competing roles. Being those whose main operating activities have a negative impact to social health but on the other side, their CSR activities are quite significant and well known in Indonesia. Therefore, the main focus in this research is to examine the associations between the CSR activities and the company's financial performance.

\section{Methodology}

This research used 3 cigarettes companies, namely PT Gudang Garam Tbk., PT Hanjaya Mandala Sampoerna Tbk., and PT. Bentoel Internasional Investama, as the populations for period of 8 years from 2007- 2014. The Author used simple linear regression to examine the association between CSR disclosure and financial performance.

The analysis of the model used panel data regression analysis which combines the time series and cross section data. The purpose of this test is to determine the association between independent variable and dependent variable by using Eviews 6.0 software for Windows. The independent variable in this research is CSR Index (CSDI), while the dependent variables used are ROA, ROE, and Stock Return (SR).

First: The instrument used in this variable is the CSR disclosure checklist which consists of 79 items. This checklist was created based on Global Reporting Initiatives (GRI).

Determining the value of disclosure index checklist of CSR were performed by using the dichotomy approach, means that each disclosure items of CSR in the instrument is given a score of one (1) for each item disclosed, and a score of zero (0) for each item that was not disclosed. So, the CSR disclosure index is calculated by the formula: the total items disclosed divided by the total score of items disclosed added with the total items that are not disclosed.

Second: ROA is calculated by dividing the earnings after taxes to the total assets, while ROE also divides the earnings after taxes to the total equity. On the other hand, the stock return is calculated by dividing the difference between the stock price index of individual companies and the year before, with individual company stock price index in the previous year.

Third: To determine which approach the researcher used in panel data regression, the Chow (F-Statistics) and Hausman tests were performed.

If the F-Statistics or F-Chow value is higher than F-table, then $\mathrm{H} 0$ is rejected, it means that fixed effect approach used followed by the Hausman test. But, if F-Chow value is smaller than F-table, then it fails to reject $\mathrm{H} 0$, it means that the pooled least square or summon effect approach is chosen. When PLS is used, the Hausman test does not need to be conducted.

If the result of F-Chow test stated that fixed effect approach were used, then the next test was Hausman Test, in order to determine whether the fixed effect approach or random effect approach that would be used. This test use Chi-square value, if the probability value is smaller than the significant test result $(\alpha)$, and then H0 is rejected, which means that fixed effect approach is used. Otherwise, if the probability of Hausman is higher than $\alpha$, 
then fail to reject $\mathrm{H} 0$, which means random effect approach is chosen.

Fourth: Analysis of hypothesis testing. The test used is the t-test (partial test) with a confidence level $95 \%$ or estimation error $(\alpha)$ of $5 \%$.

Probability Test is conducted to find the effect of each variable towards the dependent variable partially; with the significance level $(\alpha)$ is 0.05 or $5 \%$. The hypotheses are as follows:

- If the probability $\leq \alpha$, then $\mathrm{H} 0$ is rejected. There is a significant association between independent variable and the dependent variable partially.

- If the probability $>\alpha$, then it is fail to reject H0. There is no a significant association between independent variable and the dependent variable partially.

Fifth: Conducting Regression Analysis of CSR Disclosure Index (CSDI) towards ROA, ROE, and Stock Return.

\section{Findings}

Table 1 and 2 below summarized descriptive statistics of variables used in this research.

Table 1. Descriptive Statistics Relating to Variables

\begin{tabular}{cccccc}
\hline & $\mathrm{N}$ & Minimum & Maximum & Mean & Std. deviation \\
\hline ROA & 24 & -.2223 & .4162 & .1358 & .1632 \\
ROE & 24 & -1.1817 & 1.6313 & .3003 & .4939 \\
SR & 24 & -.4940 & 4.0700 & .3683 & .9236 \\
CSDI & 24 & .3671 & .5063 & .425631 & .0398232 \\
\hline
\end{tabular}

Variable definitions

ROA : Earnings after taxes divided by total assets owned by the company.

ROE : Earnings after taxes divided by total equity of the company.

SR : Difference between the stock price index of individual companies and the year before divided by individual company stock price index in the previous year.

CSDI : Total items disclosed divided by the total score of items disclosed added with the total items that are not disclosed.

Table 2. Cross-Section Random Effects Regressions for ROA

\begin{tabular}{ccc}
\hline Variable & Exp. Sign & \multicolumn{1}{c}{ CSDI } \\
\hline $\mathrm{C}$ & - & -.260316 \\
& & $(.2351)$ \\
ROA & + & $.930653^{* *}$ \\
& & $(.0206)$ \\
\hline Observations & & 24 \\
Adjusted $R^{2}$ & & .19 \\
Prob $>F$-test & & .02 \\
\hline
\end{tabular}

Based on the results of the regression calculation of ROA in table 2, the value of coefficient of $\alpha=-0.260316$ and $\beta=0.930653$. Therefore the regression equation now can be formulated as follow:

$$
\mathrm{Y} 1=-0.260316+0.930653 \mathrm{CSDI}+\mathrm{e}
$$

The coefficient of CSDI variable is equal to 0.930653, it means that if the CSR disclosure is increase one unit, then Return on Assets (ROA) will increase by 0.930653 and vice versa. If the CSR disclosure is decrease one unit, then the Return on Assets (ROA) will decrease by 0.930653 , with the assumption that the other variable is constant. The value of Constanta is -0.260316 , it means that if there is no variable, and then the value of Return on Assets (ROA) is -0.260316 . 
Table 3. Cross-Section Random Effects Regressions for ROE

\begin{tabular}{ccc}
\hline Variable & Exp. Sign & CSDI \\
\hline $\mathrm{C}$ & + & .912975 \\
& & $(.4196)$ \\
$\mathrm{ROE}$ & - & 1.439342 \\
& & $(.5792)$ \\
\hline Observations & & 24 \\
Adjusted $R^{2}$ & & -.03 \\
Prob $>F$-test & & .57 \\
\hline
\end{tabular}

Based on the results of the regression calculation of ROE in table 3, it shows the value of coefficient of $\alpha=0.912975$ and $\beta=-1.439342$. Therefore the regression equation now can be formulated as follow:

$$
\mathrm{Y} 2=0.912975-1.439342 \mathrm{CSDI}+\mathrm{e}
$$

The coefficient of CSDI variable is equal to -1.439342 , it means that if the CSR disclosure is increase one unit, then Return on Equity (ROE) will increase by -1.439342 and vice versa. If the CSR disclosure is decrease one unit, then the Return on Equity (ROE) will decrease by -1.439342 , with the assumption that the other variable is constant. The value of Constanta is 0.912975 , it means that if there is no variable, then the value of Return on Equity (ROE) is 0.912975.

Table 4. Pooled Least Square Regressions for SR

\begin{tabular}{ccc}
\hline Variable & Exp. Sign & CSDI \\
\hline $\mathrm{C}$ & - & .1797 \\
$\mathrm{SR}$ & & $(.9329)$ \\
& + & 1.2877 \\
& & $(.7967)$ \\
\hline Observations & & 24 \\
Adjusted $R^{2}$ & & -.04 \\
Prob $>F$-test & & .80 \\
\hline
\end{tabular}

Based on the results of the regression calculation of Return Stock in table 4, it shows the value of coefficient of $\alpha=-0.1797$ and $\beta=1.2877$. Therefore the regression equation now can be formulated as follow:

$$
\mathrm{Y} 3=-0.1797+1.2877 \mathrm{CSDI}+\mathrm{e}
$$

The coefficient of CSDI variable is equal to 1.2877; it means that if the CSR disclosure is increase one unit, then Stock Return will increase by 1.2877 and vice versa. If the CSR disclosure is decrease one unit, then the Stock Return will decrease by 1.2877 , with the assumption that the other variable is constant. The value of Constanta is -0.1797 , it means that if there is no variable, and then the value of Stock Return is -0.1797 .

The result proves that the disclosure of CSR only have positive influences toward the companies' ROA, while its not correlate with the companies' ROE and Stock Return. It means that although the results indicate that the improvement of CSR information disclosure makes cigarettes companies has a chance to improve its management efficiency at using its assets to generate earnings (ROA), in a short term it will not affect their efficiency to generate profits from its shareholders investments in the company (ROE) nor affecting an investor's decision to invest on them.

Based on the result of this study, the significance value of ROA is less than 0.05 , which is 0.0206 . It proves that the disclosure of CSR (CSDI) activities has a positive association on ROA. Therefore the hypothesis (H1) is supported. This result supports the previous research conducted by [14]. The CSR indexes provide support for company to build image, 
maintaining reputation and legitimacy of investors to increase capacity of company. This was consistent with the statement of [14], that participation in various forms of CSR can provide many benefits for company.

Meanwhile, this study showed an opposite result for ROE. The significance value is greater than of $0.05 \%$, which is 0.5792 to be exact. This indicates that the disclosure of the CSR activities did not have a significant association on the ROE. Thus the hypothesis (H2) is not supported. It is also supported by previous studies conducted by [15].

The disclosure of CSR activities are still less effective to stimulate an increase in ROE because the purpose is to generate profits in the long term; while ROE is an indicator for short term financial performance. The unstable fluctuation of ROE in cigarettes companies is one that can be the cause of this inconsistency results. There is a pretty high standard deviation in each year which means high risk for investment in the tobacco industry because of the uncertainty [16]. Given that, the disclosure of CSR is not the only the reason for investors to invest.

CSR has no significant association toward Stock Return. The significance value is greater than of $0.05 \%$, which is 0.7967 . This indicates that the disclosure of the CSR (CSDI) activities did not have a significant association on the company's Stock Return (SR) ratio.

CSR is a long-term investment for the company. By revealing the activity of their social responsibility, the company tried to mingle with the public so that their economy activities can be accepted by society. This supports the stakeholder theory in the sense that the stakeholders have the same rights as the shareholder, who allowed them to put their demands and needs towards the company [17]. In this case the company's relationship with stakeholders is called CSR, and by paying attention to their needs, the demand of stakeholders will assist the management in order to make a better decision. Furthermore, the results can be used as one of the considerations for investors to invest in companies that have a commitment toward CSR activities, and also reduce the assumption which said that the implementation of CSR will reduces the expected return for investors. Similarly for the management division, we hope that in the future they will pay more attention to the effective implementation of CSR, so that it will be able to encourage the companies to have better performances, hoping that in the future the cigarette companies can also compete with other multinational companies to deal with the global competition.

\section{Conclusion}

This study showed that CSR index can increase company's performance in form of ROA in listed cigarettes companies during 2007-2014. However, the CSR does not have a significant association with the ROE. Moreover, the CSR disclosure does not have a significant association with the Stock Return since this study revealed that CSR index does not increase company's performance in form of Stock Return in listed cigarettes companies during 2007-2014.

\section{References}

1. Hamdani. D., Gatra (2013)

2. McWilliams. A., D. Siegel, Acad Manag. Rev., 26, 1 (2001)

3. Khan, R.M. and A. Hassan, IJCRB, 4, 10 (2013)

4. F. R. Council, Thinking About Disclosures in A Broader Context. A Road Map for a Disclosure Framework (2012)

5. Purwanto. A., Akuditi, 8, 1 (2011)

6. Murtanto, International Business Management Conference (2004)

7. Jitaree. W., School of Accounting, Economics and Finance (2015) 
8. Soemarso. S.R., Akuntansi: Suatu Pengantar 1 (2004)

9. Sugiono. A., Manajemen Keuangan Untuk Praktisi Keuangan (2009)

10. Sudana. I.M., Manajemen Keuangan Perusahaan; Teori \& Praktek (2009)

11. Samsul. M., Pasar Modal \& Manajemen Portofolio (2006)

12. Hartono. J., Analisis dan desain sistem informasi (2005)

13. Republik, I., Limited Liability Company (Perseroan Terbatas) (2007)

14. Setiawan, M., Darmawan, European Journal of Social Sciences, 23, 2 (2011)

15. Budianto. J.Th., L.N.F., Majalah Ekonomi, 18, 1 (2008)

16. Bains, A. What Is Standard Deviation? (2011)

17. Goukasian, L. and L.K. Whitney, Corporate Socially Responsible Firms Perform Well! Evidence from Financial and Operating Performances (2008) 